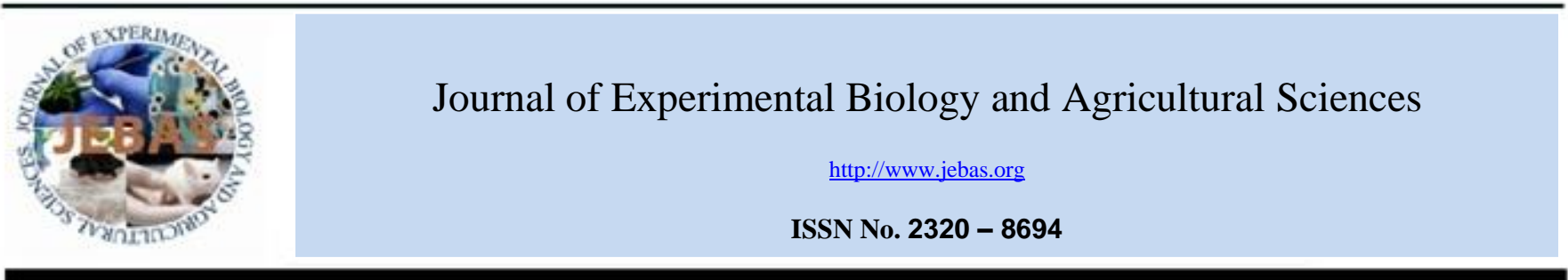

\title{
A COMPARATIVE PHARMACOGNOSTIC STUDY OF THE TWO Orthoshipon aristatus (BLUME) MIQ. VARIETIES
}

\author{
Fahrauk Faramayuda* ${ }^{1,2}$, Silvy Julian², Ari Sri Windyaswari ${ }^{2}$, Totik Sri Mariani ${ }^{3}$, \\ Elfahmi $^{1,4}$, Sukrasno $^{1}$
}

\footnotetext{
${ }^{1}$ School of Pharmacy, Institut Teknologi Bandung (ITB), Bandung, West Java, Indonesia

${ }^{2}$ Faculty of Pharmacy Universitas Jenderal Achmad Yani (UNJANI), Cimahi, West Java, Indonesia

${ }^{3}$ School of Life Sciences and Technology, Institut Teknologi Bandung (ITB), Bandung, West Java, Indonesia

${ }^{4}$ Biosceinces and Biotechnology Research Center, Institut Teknologi Bandung (ITB), Bandung, West Java, Indonesia

Received - December 14, 2020; Revision - March 19, 2021; Accepted - May 03, 2021

Available Online - September 08, 2021
}

DOI: http://dx.doi.org/10.18006/2021.9(Spl-2-ICOPMES_2020).S228.S233

\section{KEYWORDS \\ Orthosiphon aristatus \\ Purple variety \\ White variety \\ Crude drugs characteristic}

\begin{abstract}
The use of a plant as an ingredient in traditional medicine requires scientific evidence to determine its properties. Cat's whiskers (Orthosiphon aristatus) is one of the widely used traditional medicinal plants in various Asian and European countries. This study aimed to determine the pharmacognostic properties of purple and white varieties of $O$. aristatus. Aqueous and ethanolic extract of the stem and leaves of purple and white varieties of $O$. aristatus was prepared and investigated for the presence of active ingredients. The $\mathrm{AlCl}_{3}$ colorimetric method was used for the estimation of flavones and flavonols. The level of flavonoid was reported $13.06 \pm 0.13 \mathrm{mg} \mathrm{QE} / 1 \mathrm{~g}$ and $6.17 \pm 0.049 \mathrm{mg} \mathrm{QE} / \mathrm{g}$ for the leaves and stem extracts of purple varieties respectively while this value was reported $9.76 \pm 0.15 \mathrm{mg} \mathrm{QE} / 1 \mathrm{~g}$ and $3.79 \pm 0.03 \mathrm{mg} \mathrm{QE} / 1 \mathrm{~g}$ for the white variety. From the results of the study, it can be concluded that the purple variety has a significantly higher amount of flavonoid then the white variety.
\end{abstract}

* Corresponding author

E-mail: ramayuda.f@gmail.com (Fahrauk Faramayuda)

Peer review under responsibility of Journal of Experimental Biology and Agricultural Sciences.

Production and Hosting by Horizon Publisher India [HPI] (http://www.horizonpublisherindia.in/).

All rights reserved.
All the articles published by Journal of Experimental Biology and Agricultural Sciences are licensed under a Creative Commons Attribution-NonCommercial 4.0 International License Based on a work at www.jebas.org.

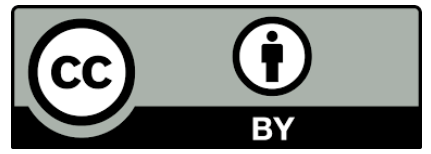




\section{Introduction}

The plants are used as an active ingredient in traditional medicine from the ancient time but scientific evidence in favour of these uses are in scanty. Detailed investigation of the active ingredients available in medicinal plants also help in justifies the use of the particular plant in the traditional medicinal system (Nuari et al., 2017). O. aristatus is a medicinal plant which widely used as ingredients in various traditional medicine, cosmetics, and food supplements in various Asian and European countries. Some important pharmacological activities of $O$. aristatus are antidiabetic (Mohamed et al., 2011), antiviral (Ripim et al., 2018; Faramayuda et al., 2021a), antioxidants (Alshawsh et al., 2012), antiepileptic (Kar et al., 2018), and antimicrobial (Chen, 1989; Hossain et al., 2007; Ho et al., 2010). Further, in traditional medicine, this plant is extensively used for the prevention and treatment of various remedies such as cancer (Halim et al., 2017; Pauzi et al., 2018), rheumatoid arthritis (Adawiyah et al., 2018), gastric disorders (Yuniarto et al., 2017), cardiac dysfunction (Abraika et al., 2012), and improving memory (George et al., 2015). Cai et al. (2018) also suggested that $O$. Stamineus protect intestinal cells from oxidative stress and the stem have high antioxidant activity (Ameer et al., 2012; Xue et al., 2016).

Previous studies reported the presence of various secondary metabolites such as polyphenols (lipophilic flavonoids and phenolic acids), terpenoids (diterpenes and triterpenes), and sterols (Tezuka et al., 2000) from the O. aristatus. Olah et al. (2017) also reported the presence of caffeic acid (rosmarinic acid, cycoric acid) and polymoxylated flavonoids (sinensetin, eupatorin) derivatives from this plant. Further, the presence of the caffeine acid derivatives, triterpene saponins, diterpenes esters, essential oils and flavonoids was also reported from the stem of O.aristatus (Tezuka et al., 2000).

Based on the colour of the petals of flowers $O$. aristatus can be classified into three varieties, namely white, white-purple, and purple (Lai Keng \& Poay Siong, 2006; Febjislami et al., 2019; Faramayuda et al., 2020; Faramayuda et al., 2021b; Faramayuda et al., 2021c). While, the stem colour of the purple variety is light purple, and for the white variety it is green-brown. Information regarding the pharmacognostic characteristics and the level of flavonoids of these $O$. aristatus varieties are limited. Therefore, this study was carried out to compare the levels of flavonoids in the leaves and stems of white and purple varieties of the $O$. aristatus.

\section{Materials and Methods}

\subsection{Chemicals and reagents}

The chemicals used in this study are analytical (pro analysis, p.a) grade ethanol $96 \%$, toluene, quercetin, aluminum chloride $10 \%$ and potassium acetate.

\subsection{Collection of plants}

The leaves and stems of purple and white varieties of $O$. aristatus were collected from the Manoko experimental garden, West Bandung, Indonesia. Collected plants were taxonomically identified by a qualified taxonomist and a type specimen was deposited at the herbarium of School of Life Science and Technology, Institut Teknologi Bandung. The collected plant samples were air-dried and powdered. The powder crude drug is then sieved using a sieving machine with a mesh sieve of $20 / 40$ and 40/60 to obtain a powder of a suitable and uniform size.

\subsection{Characterization of Plant Material}

\subsubsection{Water and Ethanol Soluble Contents}

For the estimation of water-soluble contents, 5 grams of leaves and stem powder was macerated for 24 hours with $100 \mathrm{~mL}$ of water in a separating funnel. This apparatus was manually shacked many times for the first 6 hours and later on left stable for the next 18 hours. Filtrate $(20 \mathrm{~mL})$ was evaporated to dryness under oven at $105^{\circ} \mathrm{C}$ in a tapered evaporator cup until a constant weight was gained. A similar procedure was used for the estimation of ethanol-soluble content, in this, instead of water, $100 \mathrm{~mL}$ of ethanol was used in a closed flask for separation.

\subsubsection{Determination of Water Content (Distillation Method)}

In this study, the toluene distillation method was used to determine the water content (Hermawan et al., 2016). An appropriate amount of the crude sample was weighed and mixed with $200 \mathrm{~mL}$ of toluene in a flask. The cooling and receiving tubes that have been cleaned and dried were connected with the flask and this distillation apparatus was heated for 15 minutes. When the toluene started boiling the temperature was adjusted in such a manner that it preceded the distillation at the rate of 2 drops per second until the water has been completely distilled.

\subsection{Extraction of Plant Material}

A total of $100 \mathrm{~g}$ of leaves and stems two varieties of $O$. aristatus mixed with $300 \mathrm{~mL} 96 \%$ ethanol solvent and stored for maceration. The apparatus was manually shacked many times for the first 6 hours and later on left stable for the next 18 hours (Utami et al., 2016). The extraction process is repeated twice with the same type and amount of solvent to gain the maximum concentration of extract. All macerate was collected and concentrated by evaporating using a rotary evaporator, and this was followed by water bath evaporation till the thick extract is obtained. 


\subsubsection{Determination of Specific Gravity}

Determination of specific gravity was based on a $5 \%$ dilution of the extract in an ethanol solvent by using a pycnometer. Before determining the specific gravity, the pycnometer was properly cleaned and dried. The pycnometer was calibrated by weighing its weight and the weight of water at $25^{\circ} \mathrm{C}$. Similarly, the specific gravity of the extract was determined by a pycnometer at $25^{\circ} \mathrm{C}$. The extract's specific gravity is determined by dividing the weight of extract by the weight of water in a pycnometer at $25^{\circ} \mathrm{C}$.

\subsubsection{Determination of Flavonoid Levels}

\subsubsection{Sample preparation for Quercetin Calibration Curve}

Quercetin $(25 \mathrm{mg})$ was taken into a $50 \mathrm{~mL}$ volumetric flask and dissolved in $25 \mathrm{~mL}$ pro-analysis ethanol $(1000 \mu \mathrm{g} / \mathrm{mL}$ stock solution). This was followed by the making of a standard solution of quercetin. For this, $0.5 \mathrm{~mL}$ of the standard solution was pipette out, and in this $1.5 \mathrm{~mL}$ pro-analysis ethanol, $0.1 \mathrm{~mL} 10 \%$ aluminum chloride, $0.1 \mathrm{~mL}$ potassium acetate and $2.8 \mathrm{~mL}$ distilled water was added. After that, this mixture was incubated at room temperature for 30 minutes; and the mixture's absorbance was measured by a UV-Visible spectrophotometer.

\subsubsection{Preparation of Sample Solution}

The ethanol extract of the leaves and stems of purple and white varieties of cat's whiskers was prepared by Azizah et al. (2014) method, for this, $1.0 \mathrm{~g}$ of each sample was taken and dissolved in the $10 \mathrm{~mL}$ of the ethanol. This mixture was stirred for 24 hours using a stirrer at a $200 \mathrm{rpm}$ speed, then filtered it, and the obtained filtrate was added to pro-analysis ethanol up to $10 \mathrm{~mL}$.

\subsubsection{Determination of Flavonoid Levels}

The level of flavonoid was determined by the $\mathrm{AlCl}_{3}$ colorimetric method that uses aluminum chloride as a reagent as described by Chang et al. (2002), and Azizah et al. (2014). $1.0 \mathrm{~mL}$ of ethanol extract was added to $10 \mathrm{~mL}$ of ethanol in a volumetric flask. From this, $0.5 \mathrm{~mL}$ of the solution was pipetted out, and mixed with a solution of $1.5 \mathrm{~mL}$ of pro-analysis ethanol, $0.1 \mathrm{~mL}$ of $10 \%$ aluminum chloride $\left(\mathrm{AlCl}_{3}\right), 0.1 \mathrm{~mL}$ of potassium acetate, and 2.8 $\mathrm{mL}$ of distilled water. In measuring flavonoid levels, the addition of potassium acetate is intended to maintain the wavelength in the visible area and detect the 7-hydroxyl group's presence. Simultaneously, the 30-minute incubation treatment is carried out before the measurement is intended so that the reaction runs perfectly to provide the maximum colour intensity. The absorbance of the mixture was measured by a UV-Visible spectrophotometer
(Chang et al., 2002). The determination of the maximum wavelength was carried out in the range of $300-600 \mathrm{~nm}$. The maximum wavelength produced was $433 \mathrm{~nm}$ at a concentration of $60 \mu \mathrm{g} / \mathrm{mL}$. The level of flavonoids had been calculated by using the following formula:

$$
\mathrm{F}(\mathrm{mg} / \mathrm{QE})=\frac{\mathrm{c} \mathrm{x} \mathrm{V}}{\mathrm{m} \times \mathrm{f} \times 10^{-6}} \times 100 \%
$$

$\mathrm{F}$ : the number of flavonoids in the $\mathrm{AlCl} 3$ method; $\mathrm{c}$ : quercetin equivalence $(\mu \mathrm{g} / \mathrm{mL})$; $\mathrm{V}$ : total extract volume $(\mathrm{mL}) ; \mathrm{m}$ : sample weight $(\mathrm{g}) ; \mathrm{f}$ : dilution factor

\subsection{Statistical Analysis}

Flavonoid levels were statistically analyzed using SPSS version 25 software using non-parametric statistical tests using the KruskalWallis Test method (Fitria et al., 2017).

\section{Results}

A detailed analytical study was carried out to characterize the leaf and stem crude extract of purple and white varieties of cat's whiskers plant. Various characteristics of crude extract such as water-soluble contents, ethanol-soluble contents and crude drug water content have been studied and the obtained values were compared with the standard reference values obtained from the Indonesian Herbal Pharmacopoeia II Edition 2017 (Table 1). In the case of observed parameters, the results of the current study revealed a non-significant difference between the stem and leaves crude extract of purple and white varieties of $O$. aristatus. Overall, the purple variety of $O$. aristatus has higher water-soluble content, Ethanol soluble content and crude drugs water content. While both varieties of $O$. aristatus have significantly higher values than the standard reference values proposed by the Indonesian Herbal Pharmacopoeia II Edition (2017).

Extraction yield with ethanol solvent was also measured for both the cat's whiskers varieties and found that leaves extract of both varieties produced maximum yield, while at the species level, maximum extract yield has been given by the white varieties. Further, determination of specific gravity was carried out by pycnometer and reported that the specific gravity of both varieties was adjacent and less than one (Table 2). The level of flavonoids was measured by the $\mathrm{AlCl}_{3}$ colorimetric method and reported that the level of flavonoids in the leaves (13.06mg QE/1g) and stems (6.17 $\mathrm{mg} \mathrm{QE} / 1 \mathrm{~g}$ ) of the purple variety were greater than those of the white variety. Further, the leaves of both $O$. aristatus varieties have higher flavonoid content than the stem (Table 2). Results of the Kruskal-Wallis test showed that the levels of flavonoids in leaves and stems of purple and white varieties had significant differences with a probability value of $0.15(\mathrm{p}<0.05)$. 
Table 1 The characteristics of the crude extract of two $O$. aristatus varieties

\begin{tabular}{|cccc|cc|}
\hline Observed Parameters & $\begin{array}{c}\text { Purple stem } \\
(\% \mathrm{w} / \mathrm{w})\end{array}$ & $\begin{array}{c}\text { White stem } \\
(\% \mathrm{w} / \mathrm{w})\end{array}$ & $\begin{array}{c}\text { Purple leaves } \\
(\% \mathrm{w} / \mathrm{w})\end{array}$ & $\begin{array}{c}\text { White leaves } \\
(\% \text { w/w })\end{array}$ & $\begin{array}{c}\text { Standard } \\
\text { Value* }\end{array}$ \\
\hline Water soluble content & $12.93 \pm 2.16$ & $12.55 \pm 0.16$ & $28.17 \pm 1.17$ & $13.18 \pm 0.47$ & $>10.2 \%$ \\
\hline Ethanol soluble content & $3.92 \pm 0.21$ & $3.45 \pm 0.18$ & $3.13 \pm 0.14$ & $2.55 \pm 0.02$ & $>7.2 \%$ \\
\hline Crude drugs water content & $2.74 \pm 0.34$ & $1.99 \pm 0.70$ & $2.00 \pm 0.71$ & $2.50 \pm 0.04$ & $<10 \%$ \\
\hline
\end{tabular}

*Standard reference values were obtained from the Indonesian Herbal Pharmacopoeia II Edition (2017)

Table 2 The yield, specific gravity and level of flavonoids in the crude extract of two $O$. aristatus varieties

\begin{tabular}{|cccc|}
\hline Sample Variety & $\begin{array}{c}\text { Extract yield } \\
(\% \mathrm{w} / \mathrm{w})\end{array}$ & $\begin{array}{c}\text { Yield Specific Gravity } \\
(\mathrm{g} / \mathrm{mL})\end{array}$ & $\begin{array}{c}\text { Levels of Flavonoids } \\
(\mathrm{mg} \text { QE } / 1 \mathrm{~g} \text { extract })^{*}\end{array}$ \\
\hline Purple Stems & 8.82 & $0.82 \pm 0.00$ & $6.17 \pm 0.049^{\mathrm{a}}$ \\
\hline White Stems & 8.39 & $0.82 \pm 0.00$ & $3.79 \pm 0.03^{\mathrm{b}}$ \\
\hline Purple Leaves & 13.43 & $0.83 \pm 0.00$ & $13.06 \pm 0.13^{\mathrm{c}}$ \\
\hline White Leaves & 14.79 & $0.83 \pm 0.00$ & $9.76 \pm 0.15^{\mathrm{d}}$ \\
\hline
\end{tabular}

*The significant difference with a probability value of $0.15(\mathrm{p}<0.05)$

\section{Discussion}

Crude extract characteristics evaluation has always been carried out to determine the general criteria of the used materials, these evaluations including both specific (determination of water-soluble content, ethanol-soluble content and flavonoid compounds) and non-specific parameters (determination of water content, and specific gravity). Results of the study revealed that the analysis of crude extract characteristics including water content, water-soluble extract content and ethanol-soluble extract content of both $O$. aristatus varieties met the requirements of the Indonesian Herbal Pharmacopoeia Edition (Anonymous, 2017). The determination of water content was aimed to provide a limit of water in the plant extracts. In this study also, obtained results of water content met the requirements of the Indonesian Herbal Pharmacopoeia Edition $(<10 \% \mathrm{v} / \mathrm{b})$.

In this study, a cold extraction method with $96 \%$ ethanol solvent was used to protect the degradation of the active substance present in the extract. Due to universal solvent properties and capability of dissolving both polar and non-polar active ingredients ethanol was used as a solvent in the current study (Utami et al., 2016). The obtained extract was concentrated by using a rotary evaporator vacuum pump, followed by evaporation of the extract over a water bath. The crude drugs used for extraction were as much as $100 \mathrm{~g}$ and produced the total yield (Table 2). Extract yield helps determine the levels of secondary metabolites in the extract (Ahmad et al., 2015). The determination of specific gravity aims to provide an overview of the dissolved chemical content in an extract. The purpose of determining specific gravity is to know the description of the limit of the mass per unit volume between the liquid extract and the thick extract that can be poured. Specific gravity can also provide an idea of the purity and contamination of the material (Anonymous, 2017).
Determining secondary metabolite compounds' levels is one of the specific parameters of standardizing the traditional medicinal ingredients. In the current study, the level of flavonoid content in leaves and stems of purple and white varieties of $O$. aristatus was carried out by the aluminum chloride colorimetric method. The principle of the aluminum chloride colorimetric method is the formation of complexes between aluminum chloride with ketone groups on $\mathrm{C}-4$ atoms and hydroxyl groups on C-3 or C-5 atoms of the flavonoids including flavone and flavonol (Chang et al., 2002). Previous studies have reported a higher level of flavonoids including sinensetin in the purple variety than the white variety; in this manner, these results are consistent with the results of the present study where the purple variety has higher flavonoids than the white variety (Lee, 2004).

Flavonols are known as markers for the presence of flavonoids because of their widespread presence in plants. In the current study, the maximum wavelength produced was $433 \mathrm{~nm}$ at a concentration of $60 \mu \mathrm{g} / \mathrm{mL}$, this measurement of the calibration curve aimed to determine the equation of the linear line. The predefined wavelengths, namely complex wavelengths of 15 standards with aluminum chloride, indicated that the complexes formed by C-3 and C-5 hydroxyl groups of flavonol such as galangine, morine, and kaempferol, also have extraorto-dihydroxyl groups such as routine, quercetin, and myricetin, the maximum absorbance was at 415-440 nm (Chang et al., 2002). Furthermore, the absorbance of each standard series solution was measured and based on the measurement results of the quercetin standard series, the equation obtained is $\mathrm{y}=0.006 \mathrm{x}+0.0697$ with a correlation coefficient $(r)=0.9992$. Ho et al. (2010) suggested that the levels of flavonoids in $O$. aristatus leaf extract with ethanol and water extract was $0.82 \%$ and $1.49 \%$ respectively. This amount was lesser than the value reported in the present study, this difference in 
flavonoid content might be due to the difference in the experimental conditions or plant materials. Cai et al. (2018) reported $170 \mu \mathrm{g}$ value of the total flavonoids in the water-ethanol extract of $O$. aristatus.

\section{Conclusion}

Pharmacognosy characteristics of the two varieties of $O$. aristatus can be a basis for selecting varieties and maintaining consistency in traditional medicines' quality. After some more detailed studies, the purple variety of $O$. aristatus can be used for the development of medicine because it has higher flavonoids and it copes up with the standard reference values of Indonesian Herbal Pharmacopoeia II Edition.

\section{Acknowledgments}

This research was funded by the Ministry of Research and Technology / National Agency for Research and Innovation (Penelitian Disertasi Doktor) with contract number 2/E1/KP.PTNBH/2020.

\section{Conflict of Interest Nil}

\section{References}

Abraika OSS, Atangwho IJ, Sadikun A, Asmawi MZ, Hussain EA (2012) In vitro activity-guided vasodilatory effect of Orthosiphon stamineus leaves. Journal of Experimental and Integrative Medicine 2 (3): 255-261. https://doi.org/10.5455/jeim.080612.or.033.

Adawiyah R, Nur B, Che A, Tantowi A, Fong S, Suhaila L (2018) Java Tea (Orthosiphon stamineus ) is protected against osteoarthritis by mitigating inflammation and cartilage degradation: a preclinical study. Inflammopharmacology.https://doi.org/10.1007/s10787-0170432-2.

Ahmad AR, Juwita J, Ratulangi SAD (2015) Determination of Total Phenolic and Flavonoid Levels of Methanol Extract of Patikala (Etlingera elatior (Jack) R.M.SM) Fruit and Leaf Extract. Pharmaceutical Sciences and Research 2 (1): 1-10. DOI: 10.7454 / psr.v2i1.3481

Alshawsh M, Abdulla M, Ismail S, Amin Z, Qader S, A Hadi H, Harmal N (2012) Free Radical Scavenging, Antimicrobial and Immunomodulatory Activities of Orthosiphon stamineus.Molecules 17:5385-5395. https://doi.org/10.3390/molecules17055385.

Ameer OZ, Salman IM, Asmawi MZ, Ibraheem ZO, Yam MF (2012) Orthosiphon stamineus: Traditional Uses, Phytochemistry, Pharmacology, and Toxicology. Journal of Medicinal Food 15 (8): 678-690. https://doi.org/10.1089/jmf.2011.1973.
Anonymous (2017) 2nd edition of the 2017 Indonesian Herbal Pharmacopeia.Ministry of Health of the Republic of Indonesia, Jakarta.

Azizah DN, Kumolowati E, Faramayuda F (2014) Determination of Flavonoid Levels using $\mathrm{AlCl} 3$ Method in Methanol Extract of Cocoa Fruit Peel (Theobroma cacao L.). Kartika Jurnal Ilmiah Farmasi 2(2):45-49.

Cai X, Xiao C, Xue H, Xiong H, Hang Y, Xu J, Lu Y (2018) A Comparative Study of The Antioxidant and Intestinal Protective Effects of Extracts from Different Parts of Java Tea (Orthosiphon stamineus). Food Science and Nutrition 6(3): 579-584.DOI: 10.1002 / fsn3.584.

Chang CC, Yang MH, Wen HM, Chern JC (2002) Estimation of total flavonoid content in propolis by two complementary colometric methods. Journal of Food and Drug Analysis 10(3):178-182.

Chen C (1989) Screening of Taiwanese crude drugs for antibacterial activity against Streptococcus. Journal of Ethnopharmacology 27(3):285-95. DOI: $\quad 10.1016 / 0378-$ 8741(89)90003-2. PMID: 2615434.

Faramayuda F, Mariani TS, Elfahmi, Sukrasno (2020) Short Communication: Callus induction in purple and white-purple varieties of Orthosiphon aristatus (Blume) Miq. Biodiversitas 21(10), 4967-4972.

Faramayuda F, Mariani TS, Elfahmi, Sukrasno (2021a) Phytochemical analysis of callus two varieties Orthosiphon aristatus (blume) miq on murashige and Skoog media. a strategic step of secondary production. International Journal of Applied Pharmaceutics 13(2): 71-77.

Faramayuda F, Mariani TS, Elfahmi E, Sukrasno S (2021b) Research Potential of Orthosiphon aristatus BlumeMiq as Antiviral : A Review, Tropical Journal of Natural Product 5: 410419.

Faramayuda F, Mariani TS, Elfahmi, Sukrasno. (2021c). Identification of secondary metabolites from callus Orthosiphon aristatus (Blume) Miq by thin layer chromatography. Sarhad Journal of Agriculture, 37(3): 1081-1088.

Febjislami S, Kurniawati A, Melati M, Wahyu Y ( 2019) Morphological characters, flowering and seed germination of the Indonesian medicinal plant Orthosiphon aristatus. Biodiversitas 20:328-337.

Fitria V, Arifin RF, Kurniasih N (2017) Activity test of pohpohan leaf extract gel (Pilea trinervia W.) against burns healing in rabbits (Oryctolagus cuniculus). Kartika: Jurnal Ilmiah Farmasi 5(2):75. doi:10.26874/kjif.v5i2.120. 
George A, Chinnappan S, Choudhary Y, Choudhary VK, Bommu P, Wong HJ (2015) Effects of a Proprietary Standardized Orthosiphon Stamineus Ethanolic Leaf Extract on Enhancing Memory in Sprague Dawley Rats Possibly via Blockade of Adenosine A 2A Receptors. Evidence-Based Complementary and Alternative Medicine2015:375837. DOI: 10.1155/2015/375837. Epub 2015 Nov 8. PMID: 26649059; PMCID: PMC4655036.

Halim NH, Pauzi N, Hamil SHR, Shafaei A, Ismail Z, Mohd KS (2017) Standardization of Orthosiphon stamineus Raw Materials and Extracts for Anti-Uterine Fibroids. International Journal of Pharmacognosy and Phytochemical Research 9 (4): 512-515.

Hermawan DS, Lukmayani Y, Dasuki UA (2016) Identification of Flavonoid Compounds in Extracts and Fractions Derived from Berenuk Fruit (Crescentia cujete L.). Pharmacy Proceedings 2(2):253-259.

Ho C, Noryati I, Sulaiman S, Rosma A (2010) In vitro antibacterial and antioxidant activities of Orthosiphon stamineus Benth. extracts against food-borne bacteria. Food Chemistry 122 (4):1168-1172 https://doi.org/10.1016/j.foodchem.2010.03.110.

Hossain MA, Ismail Z, Rahman A, Kang SC (2007) Chemical composition and anti-fungal properties of the essential oils and crude extracts of Orthosiphon stamineus Benth. Industrial Crops and Products 7:328-334.https://doi.org/10.1016/j.indcrop.2007.11.008.

Kar B, Choo M, Kundap UP, Kumari Y, Hue S, Othman I, Shaikh MF (2018) Orthosiphon stamineus Leaf Extract Affects TNF- $\alpha$ and Seizures in a Zebrafish Model. Frontiers in Pharmacology 9 (February), 1-11. https://doi.org/10.3389/fphar.2018.00139.

Lai Keng C, Poay Siong L (2006) Morphological Similarities and Differences between the Two Varieties of $O$. aristatus (Orthosiphon stamineus Benth.) Grown in Malaysia. International Journal of Botany. 2.https://doi.org/10.3923/ijb.2006.1.6.

Lee W (2004) micropropagation and cell culture of misai kucing (Orthosiphon Stamineus Benth.) and detection of rosmarinic acid in the in vitro cultures, Thesis.

Mohamed E, Mohamed AJ, Abdullah M, Sadikun A, Saad Ebrika O,
Yam M (2011) Antihyperglycemic Effect of Orthosiphon Stamineus Benth Leaves Extract and Its Bioassay-Guided Fractions. Molecules 16: 3787-3801. https://doi.org/10.3390/molecules 16053787.

Nuari S, Anam S, Khumaidi A (2017) Isolation and identification of flavonoid compounds in thick extract of bitter melon fruit. Jurnal Farmasi Galenika 2(2):118-125.

Olah NK, Hanganu D, Bodoki E, Oprean R, Toma C, Morgovan C, Gocan S (2017) Characterization of Orthosiphon stamineus Benth extracts by reversed-phase thin-layer chromatographic methods. Studia Universitatis Babes-Bolyai Chemia 62(3): 9-18.

Pauzi N, Mohd KS, Hidayah N, Halim A (2018) Orthosiphon stamineus Extracts Inhibits Proliferation and Induces Apoptosis in Uterine Fibroid Cells. Asian Pacific Journal of Cancer Prevention 19:2737-2744. https://doi.org/10.22034/APJCP.2018.19.10.2737.

Ripim M, Fazil N, Ibrahim K, Bahtiar A, Wai C, Ibrahim N, Nor M (2018) Antiviral Properties of Orthosiphon stamineus Aqueous Extract in Herpes Simplex Virus Type 1 Infected Cells. Malaysians Science 47 (8):1725-1730.

Tezuka Y, Stampoulis P, Banskota AH, Awale S, Tran KQ, Saiki I, Kadota S (2000) Constituents of the Vietnamese medicinal plant Orthosiphon stamineus. Chemical and Pharmaceutical Bulletin 48(11):1711-9. DOI: $10.1248 / \mathrm{cpb} .48 .1711$.

Utami YP, Taebe B, Fatmawati (2016) Standardization of Specific and Non-Specific Parameters of Ethanol Extract of Mulberry (Morus alba L.) Leaves from Soppeng Regency, South Sulawesi Province. Journal of Pharmaceutical and Medicinal Sciences1(2):48-52.

Xue HQ, Cai X, Xiong HH, Hang YQ, Xiao CF, Lu YH (2016) Main Nutrients and Antioxidant Capacity of Orthosiphon stamineus in Different Parts. Acta Agriculturae Shanghai (in Chinese).2(3): 3035. https://doi.org/10.15955/j.issn1000-3924.2016.03.06.

Yuniarto ARI, Susilawati E, Khairunnisa I, Juanda D, Setiawan F (2017) Antioxidant and Gastric Ulcer Healing Effect of Orthosiphon stamineus (Benth.) Leaves Extract In Aspirin-Induced Rats. Asian Journal of Pharmaceutical and Clinical Research 10 (2):2-4. DOI: http://dx.doi.org/10.22159/ajpcr.2017.v10i2.15873. 